'Effects of essential fatty acid deficiency and supplementation with docosahexaenoic acid (DHA; 22:6n-3) on cellular fatty acid compositions and fatty acyl desaturation in a cell culture model' by Douglas R. Tocher and James R. Dick. Prostaglandins, Leukotrienes and Essential Fatty Acids (PLEFA), Volume 64, Issue 1, January 2001, pp. $11-22$.

Published in Prostaglandins, Leukotrienes and Essential Fatty Acids (PLEFA) by Elsevier (Harcourt Publishers Ltd.) / International Society for the Study of Fatty Acids and Lipids.

Prostaglandins, Leukotrienes and Essential Fatty Acids (PLEFA), Volume 64, Issue 1, January 2001, pp. 11 - 22.

This is the peer reviewed version of this article.

NOTICE: this is the author's version of a work that was accepted for publication in Prostaglandins, Leukotrienes and Essential Fatty Acids (PLEFA). Changes resulting from the publishing process, such as peer review, editing, corrections, structural formatting, and other quality control mechanisms may not be reflected in this document. Changes may have been made to this work since it was submitted for publication. A definitive version was subsequently published in Prostaglandins, Leukotrienes and Essential Fatty Acids (PLEFA), VOL 64, ISSUE 1, (January 2001). DOI 10.1054/plef.2000.0233. 


\title{
Effects of essential fatty acid deficiency and supplementation with docosahexaenoic acid (DHA; 22:6n-3) on cellular fatty acid compositions and fatty acyl desaturation in a cell culture model
}

\author{
Douglas R. Tocher, James R. Dick \\ Lipid Nutrition Group, Institute of Aquaculture, University of Stirling, Stirling FK9 4LA, \\ Scotland, UK
}

Keywords: cell culture, essential fatty acid deficiency, docosahexaenoic acid, polyunsaturated fatty acids, desaturation, elongation, fish.

Correspondence to: Dr. Douglas R. Tocher, Institute of Aquaculture, University of Stirling, Stirling FK9 4LA, Scotland, U.K.; 
Tel.: +44 1786 467996; Fax: +44 1786 472133; E-mail : d.r.tocher@stir.ac.uk

Abbreviations: ANOVA, analysis of variance; BHT, butylated hydroxytoluene; BSA, bovine serum albumin; CL, cardiolipin; DHA, docosahexaenoic acid (22:6n-3); EFA, essential fatty acid; EFAD, essential fatty acid deficient; EPA, eicosapentaenoic acid (20:5n-3); FBS, fetal bovine serum; GC, gas chromatography; HBSS, Hank's balanced salt solution (without $\mathrm{Ca}^{2+}$ and $\mathrm{Mg}^{2+}$ ); HPTLC, high-performance thin-layer chromatography; PA, phosphatidic acid; PBS, Dulbecco's modification phosphate buffered saline (without $\mathrm{Ca}^{2+}$ and $\mathrm{Mg}^{2+}$ ); $\mathrm{PC}$, phosphatidylcholine; PE,phosphatidylethanolamine; PI, phosphatidylinositol; PS, phosphatidylserine; PUFA, polyunsaturated fatty acid; TLC, thin-layer chromatography; TN, total neutral lipid; TP, total polar lipid. 
Summary The desaturation of $\left[1-{ }^{14} \mathrm{C}\right] 18: 3 \mathrm{n}-3$ to docosahexaenoic acid (DHA; $\left.22: 6 \mathrm{n}-3\right)$ is enhanced in an essential fatty acid deficient cell line (EPC-EFAD) in comparison with the parent cell line (EPC) from carp. In the present study, the effects of DHA on lipid and fatty acid compositions, and the metabolism of $\left[1-{ }^{14} \mathrm{C}\right] 18: 3 \mathrm{n}-3$ were investigated in EPC-EFAD cells in comparison with EPC cells. DHA supplementation had only relatively minor effects on lipid content and lipid class compositions in both EPC and EPC-EFAD cells, but significantly increased the amount of DHA, 22:5n-3, eicosapentaenoic acid (EPA; 20:5n-3), total n-3 polyunsaturated fatty acids (PUFA), total PUFA and saturated fatty acids in total lipid and total polar lipid in both cell lines. Retroconversion of supplemental DHA to EPA was significantly greater in EPC cells. Monounsaturated fatty acids, $n-9$ and n-6PUFA were all increased in total lipid and total polar lipid in both cell lines by DHA supplementation. The incorporation of [1$\left.{ }^{14} \mathrm{C}\right] 18: 3 \mathrm{n}-3$ was greater into EPC-EFAD compared to EPC cells but DHA had no effect on the incorporation of $\left[1-{ }^{14} \mathrm{C}\right] 18: 3 \mathrm{n}-3$ in either cell line. In contrast, the conversion of $\left[1-{ }^{14} \mathrm{C}\right] 18: 3 \mathrm{n}-3$ to tetraenes, pentaenes and total desaturation products was similar in the two cell lines and was significantly reduced by DHA supplementation in both cell lines. However, the production of DHA from $\left[1-{ }^{14} \mathrm{C}\right] 18: 3 \mathrm{n}-3$ was significantly greater in EPC-EFAD cells compared to EPC cells and, whereas DHA supplementation had no effect on the production of DHA from $\left[1-{ }^{14} \mathrm{C}\right] 18: 3 \mathrm{n}$ 3 in EPC cells, DHA supplementation significantly reduced the production of DHA from [1- 
$\left.{ }^{14} \mathrm{C}\right] 18: 3 \mathrm{n}-3$ in EPC-EFAD cells. Greater production of DHA in EPC-EFAD cells could be a direct result of significantly lower levels of end-product DHA in these cells' lipids compared to EPC cells. Consistent with this, the suppression of DHA production upon DHA supplementation was associated with increased cellular and membrane DHA concentrations in EPC-EFAD cells. However, an increase in cellular DHA content to similar levels failed to suppress DHA production in DHA-supplemented EPC cells. A possible explanation is that greatly increased levels of EPA, derived from retroconversion of the added DHA, acts to offset the suppression of the pathway by DHA by stimulating conversion of EPA to DHA in DHAsupplemented EPC cells.

\section{INTRODUCTION}

The essential fatty acid (EFA) requirement for common carp (Cyprinus carpio) can be met by $1.0 \%$ of the $\mathrm{C}_{18}$ polyunsaturated fatty acids (PUFA), $\alpha$-linolenate (18:3n-3) and/or linoleate $(18: 2 n-6) .{ }^{1}$ A cell line from carp, EPC (epithelial papilloma) ${ }^{2}$ was shown to be able to convert the $\mathrm{C}_{18}$ PUFA to long-chain highly unsaturated fatty acids (HUFA) such as arachidonic (20:4n6), eicosapentaenoic (EPA; 20:5n-3) and docosahexaenoic (DHA; 22:6n-3) acids. ${ }^{3}$ We developed a cell line, EPC-EFAD, derived from EPC cells, that can survive and proliferate in an essential fatty acid-deficient (EFAD) medium based on delipidated serum despite containing virtually no n-3 and n-6HUFA. ${ }^{4,5}$ We have used these cell lines to investigate HUFA production and the pathways of fatty acid desaturation and elongation. Both cell lines desaturated the n-3 fatty acids, $\left[1-{ }^{14} \mathrm{C}\right] 18: 3 \mathrm{n}-3$ and $\left[1-{ }^{14} \mathrm{C}\right] 20: 5 \mathrm{n}-3$, to a greater extent than the $\mathrm{n}-6$ fatty acids, [1$\left.{ }^{14} \mathrm{C}\right] 18: 2 \mathrm{n}-6$ and $\left[1-{ }^{14} \mathrm{C}\right] 20: 4 \mathrm{n}-6 .{ }^{3}$ However, the desaturation of all the radiolabelled PUFA was significantly greater in EPC-EFAD cells compared to EPC cells. ${ }^{3}$ The metabolism of [1$\left.{ }^{14} \mathrm{C}\right] 18: 3 \mathrm{n}-3$ was primarily increased in EPC-EFAD cells at the level of $\Delta 5$ desaturase and 
subsequent steps in the pathway with DHA production being 4.4-fold greater in the EFAD cells. ${ }^{3}$ In a recent study, the effects of competing, unlabeled $C_{18}$ PUFA, 18:2n-6, 18:3n-3, 18:3n-6 and 18:4n-3, on the metabolism of $\left[1-{ }^{14} \mathrm{C}\right] 18: 3 \mathrm{n}-3$ were investigated. ${ }^{6}$ The incorporation of $[1-$ $\left.{ }^{14} \mathrm{C}\right] 18: 3 n-3$ in both EPC and EPC-EFAD cell lines was significantly reduced, and the proportions of radioactivity recovered in DHA, pentaene and tetraene products significantly decreased, by competing $\mathrm{C}_{18}$ PUFA. $^{6}$ However, the inhibitory effect of competing $\mathrm{C}_{18}$ PUFA on the desaturation of $\left[1-{ }^{14} \mathrm{C}\right] 18: 3 \mathrm{n}-3$ was significantly greater in EPC-EFAD cells although the mechanism for this was unclear. The magnitude of the inhibitory effects of $\mathrm{C}_{18}$ PUFA on [1$\left.{ }^{14} \mathrm{C}\right] 18: 3 \mathrm{n}-3$ desaturation was dependent upon the specific fatty acid and its position in the fatty acid desaturation pathway with, for instance, $18: 4 n-3$ producing a greater inhibition than 18:3n-

3. Thus the effects of $18: 4 n-3$ were probably a combination of product inhibition of $\Delta 6$ desaturation of $\left[1-{ }^{14} \mathrm{C}\right] 18: 3 \mathrm{n}-3$ and also by direct substrate competition for $\mathrm{C}_{18-20}$ elongase and subsequent steps in the pathway.

In summary, the previous studies had shown that the main effect of essential fatty acid deficiency on fatty acid desaturation in carp cells was increased production of DHA, that competing fatty acids showed far greater inhibition of fatty acid desaturation in EPC-EFAD cells, and that competing acids had differential effects based on their position in the desaturation/ elongation pathway. Therefore, in the present study, rather than looking at the effects of competing substrate fatty acids, we have investigated the effects of DHA, as both final end product of the pathway and as the HUFA whose production is most influenced by EFA deficiency, on the metabolism of $\left[1-{ }^{14} \mathrm{C}\right] 18: 3 n-3$ in EPC and EPC-EFAD cells. Specifically, both cell lines were grown in the presence or absence of DHA after which the cultures were washed and the activities of the fatty acid desaturation/ elongation pathway were determined by incubation with $\left[1-{ }^{14} \mathrm{C}\right] 18: 3 \mathrm{n}-3$. The effects on fatty acid incorporation and desaturation were 
determined and related to the effects of DHA supplementation on cellular lipid and fatty acid compositions.

\section{MATERIALS AND METHODS}

\section{Cells and media}

The carp (Cyprinus carpio) epithelioma papillosum (EPC) cell line, which retains epithelial morphology, was routinely maintained in Leibovitz L-15 medium and supplemented with $2 \mathrm{mM}$ glutamine, antibiotics (50 I.U. ml ${ }^{-1}$ penicillin and $50 \mathrm{mg} \cdot \mathrm{ml}^{-1}$ streptomycin) and $10 \%$ fetal bovine serum (FBS). ${ }^{2}$ EPC-EFAD cells were derived from EPC cells by subculture in Leibovitz L-15 medium with exactly the same supplements except that the FBS was delipidated prior to use, essentially as described by Capriotti and Laposata. ${ }^{7}$ Delipidated serum had been used previously to develop cultured mammalian cell lines that can grow in the absence of EFA. ${ }^{8-10}$ The delipidated FBS contained approximately $10 \mu \mathrm{g}$ of fatty acids per $\mathrm{g}$ of serum $(0.001 \%$ by weight $)$ with less than $2 \mu \mathrm{g} / \mathrm{g}$ of $\mathrm{C}_{18}$ PUFA, predominantly 18:2(n-6). ${ }^{4,5}$ The EPC-EFAD cells used in the experiments had been maintained continuously in delipidated medium for over 5 years and were at passage number 100 .

\section{Incubation conditions}

The EPC and EPC-EFAD cells were cultured at $22{ }^{\circ} \mathrm{C}$ in sealed plastic tissue culture flasks. EPC cells were cultured in standard tissue culture flasks (Iwaki Flasks, Asahi Techno Glass, Chiba, Japan), whereas the EPC-EFAD line was cultured in surface-modified "Primaria" flasks

(Falcon, Becton Dickinson UK Ltd., Oxford). Both EPC and EPC-EFAD lines were cultured in $75 \mathrm{~cm}^{2}$ flasks and were subcultured within $24 \mathrm{~h}$ of reaching confluence at seeding densities of 1 
$\mathrm{x}$, and $2 \times 10^{5}$ cells.cm ${ }^{-2}$, respectively, to account for the slower proliferation rate of the EPCEFAD cells in delipidated FBS. ${ }^{4,5}$ For each experimental sample, $3 \times 75 \mathrm{~cm}^{2}$ flasks were seeded and this experiment was repeated three times to obtain the replicates.

\section{Supplementation of cultures with $22: 6 n-3$ and incubation with $\left[1-{ }^{14} \mathrm{C}\right] 18: 3 \mathrm{n}-3$}

The medium was aspirated, the cultures washed with Dulbecco's phosphate-buffered saline (PBS) and fresh Leibovitz L-15 medium, as above and including 10\% serum or delipidated serum, was added. For each cell line, half the flasks received 22:6n-3, added at a final concentration of $20 \mu \mathrm{M}$, bound to fatty acid-free bovine serum albumin (BSA) in PBS. ${ }^{11}$ The remaining flasks of each cell line cultured without supplementary DHA received an equal volume of fatty acid-free BSA-PBS solution. Flasks were incubated at $22{ }^{\circ} \mathrm{C}$ for 3 days before a second dose of $20 \mu \mathrm{M}$ unlabeled 22:6n-3 was applied to the cells and incubation continued for a further 3 days at $22{ }^{\circ} \mathrm{C}$. After this preincubation period with $22: 6 n-3$, the medium was again aspirated, the cultures washed twice, first with Hank's balanced salt solution without calcium and magnesium (HBSS) containing $1 \%$ fatty acid-free BSA and then with PBS, and fresh Leibovitz L-15 medium, as above but without serum, was added. The $\left[1-{ }^{14} \mathrm{C}\right] 18: 3 \mathrm{n}-3(0.25 \mu \mathrm{Ci}$ per flask; concentration, $1.0 \mu \mathrm{M}$ ) was added to all flasks as fatty acid-free BSA-PBS complexes prepared as described previously ${ }^{12}$ and incubation continued for 4 days at $22{ }^{\circ} \mathrm{C}$.

\section{Lipid extraction and incorporation of radioactivity into total lipid}

The medium was aspirated and cultures washed twice with $20 \mathrm{ml}$ of ice-cold HBSS. Cells were harvested by trypsinization with $0.05 \%$ trypsin $/ 0.5 \mathrm{mM}$ ethylenediamine tetraacetic acid (EDTA), washed first with $5 \mathrm{ml}$ ice-cold HBSS containing $1 \%$ fatty acid-free BSA and then with $5 \mathrm{ml}$ HBSS. An aliquot of $50 \mu \mathrm{l}$ of the cells was taken and protein determined according to the 
method of Lowry et $\mathrm{al}^{13}$ after incubation with $0.2 \mathrm{ml}$ of $0.25 \%(\mathrm{w} / \mathrm{v})$ sodium dodecyl sulfate/1M $\mathrm{NaOH}$ for $45 \mathrm{~min}$ at $60^{\circ} \mathrm{C}$. Total lipid was extracted from the cell pellets with $5 \mathrm{ml}$ ice-cold chloroform/methanol $(2: 1, \mathrm{v} / \mathrm{v})$ containing $0.01 \%$ butylated hydroxytoluene $(\mathrm{BHT})$ as antioxidant, essentially according to Folch et $\mathrm{al}^{14}$ as described in detail previously. ${ }^{15}$ Lipid content was determined gravimetrically after $1 \mathrm{~h}$ vacuum desiccation and the lipid resuspended in chloroform/methanol $(2: 1, \mathrm{v} / \mathrm{v})$ containing BHT, at a lipid concentration of $10 \mathrm{mg} \cdot \mathrm{ml}^{-1}$, and samples stored at $-20{ }^{\circ} \mathrm{C}$ before analyses. The radioactive content of total lipid was determined in 3 aliquots of $5 \mu \mathrm{l}$ in mini-vials containing $2.5 \mathrm{ml}$ scintillation fluid (Ecoscint A; National Diagnostics, Atlanta, U.S.A.) using a TRI-CARB 2000CA liquid scintillation spectrophotometer (United Technologies Packard). Results were corrected for counting efficiency and quenching using an appropriate calibration curve. All solvents contained $0.01 \%$ BHT as antioxidant.

\section{Separation of total polar lipids and fatty acid analysis}

Samples of total lipid $(300 \mu \mathrm{g})$ were applied as $3 \mathrm{~cm}$ streaks to thin-layer chromatography (TLC) plates, and polar lipids separated from neutral lipids using hexane/diethyl ether/acetic acid (90:10:1, by vol.) as developing solvent. The origin area corresponding to total polar lipids was scraped into stoppered conical glass test tubes for transmethylation directly on the silica. ${ }^{16}$ Fatty acid methyl esters (FAME) of total cell lipid or total polar lipids, purified as above, were prepared by acid-catalyzed transmethylation, and extracted and purified by high-performance TLC (HPTLC) as described previously. ${ }^{17}$ Analysis of FAME was performed by capillary gas chromatography in a Fisons GC8000 gas chromatograph (Crawley, UK) equipped with a fusedsilica capillary column (30m x $0.32 \mathrm{~mm}$ i.d., CP Wax $52 \mathrm{CB}$, Chrompack, UK) using hydrogen as carrier gas. Temperature programming was from 50 to $150^{\circ} \mathrm{C}$ at $35^{\circ} \mathrm{C} / \mathrm{min}$ and to $225^{\circ} \mathrm{C}$ at 
$2.5^{\circ} \mathrm{C} / \mathrm{min}$. Individual FAME were identified by comparison with known standards and published data. ${ }^{18,19}$

\section{Incorporation of radioactivity into polyunsaturated fatty acids}

TLC plates were impregnated by spraying with $2 \mathrm{~g}$ silver nitrate in $20 \mathrm{ml}$ acetonitrile and activated at $110{ }^{\circ} \mathrm{C}$ for $30 \mathrm{~min}$. Total lipid FAME were applied as $2.5 \mathrm{~cm}$ streaks and plates developed with toluene/acetonitrile $(95: 5, \mathrm{v} / \mathrm{v})$ to separate PUFA. ${ }^{20}$ Autoradiography was performed using Kodak MR2 film for 6 days at room temperature. Silica corresponding to different FAME was scraped into scintillation vials containing $2.5 \mathrm{ml}$ scintillation fluid and radioactivity determined as described above.

\section{Materials}

$\left[1-{ }^{14} \mathrm{C}\right] 18: 3 \mathrm{n}-3$ (50 mCi.mmol ${ }^{-1}$ and $99 \%$ pure) was obtained from NEN Life Science Products (Hounslow, U.K.). Unlabeled 22:6n-3 (approx. 98\% pure), Leibovitz L-15 medium, HBSS, PBS, glutamine, penicillin, streptomycin, FBS, trypsin/EDTA , fatty acid-free BSA and BHT were obtained from Sigma Chemical Co. Ltd. (Poole, UK). TLC plates $(20 \mathrm{~cm} \mathrm{x} 20 \mathrm{~cm}$ x 0.25 $\mathrm{mm})$ and HPTLC plates $(10 \mathrm{~cm}$ x $10 \mathrm{~cm}$ x $0.15 \mathrm{~mm})$, pre-coated with silica gel 60 were obtained from Merck (Darmstadt, Germany). All solvents were of HPLC grade and were obtained from Rathburn Chemicals (Walkerburn, Peebleshire, Scotland).

\section{Statistical analysis}

All results are means \pm SD of three experiments. Where indicated, data were subjected to twoway and/or one-way analysis of variance (ANOVA) to determine the significance of effects due to cell line and fatty acid supplement, and where appropriate the significance of differences were 
determined by Tukey's post-test. Percentage data were subjected to arc-sin transformation prior to further statistical analysis. Differences are reported as significant when $p<0.05 .^{21}$

\section{RESULTS}

The lipid contents and class compositions of the EPC and EPC-EFAD cell lines are shown in Table 1. The data were subjected to two-way analysis of variance (ANOVA) to determine the significance of effects due to EFA deficiency and DHA supplementation (Table 2). The lipid content of the cells relative to protein content was not significantly affected by EFA deficiency and DHA supplementation also had no significant effect in either cell line. EPC-EFAD cells were characterised by significantly decreased proportions of cholesterol and phosphatidylcholine (PC), and significantly increased proportions of phosphatidylethanolamine (PE), phosphatidylinositol (PI) and total polar lipids (Tables 1 and 2). Supplementation with DHA significantly increased the proportions of total polar lipids in both cell lines. However, whereas DHA supplementation decreased the proportions of cholesterol and PE and increased the proportion of PC in EPC cells, it had little effect on the relative proportions of these three major lipid classes in EPC-EFAD cells (Table 1).

There was no significant difference in total fatty acid content of the two cell lines when the results were expressed relative to protein content and although DHA supplementation tended to increase the total fatty acid content in both cell lines, these effects were non significant (Table 3 ). Expressing the total lipid fatty acid composition of the cell lines relative to cell protein content showed that EPC-EFAD cells contained very reduced amounts of n- 6 and n-3 PUFA which was compensated entirely by increased amounts of n-9 PUFA so that total PUFA content was identical in the two cell lines. The levels of saturated fatty acids in total lipid were slightly lower in EPC-EFAD cells mainly due to reduced 16:0 and 18:0 whereas the levels of total 
monounsaturated fatty acids were identical in the two cell lines despite EPC-EFAD cells showing a lower level of 18:1n-9. DHA supplementation increased the levels of DHA, 22:5n-3, EPA, total n-3PUFA, total PUFA and total saturated fatty acids in total lipid in both cell lines and decreased the amounts of n-9 PUFA and monoenes, particularly 18:1n-9 (Table 3). These effects of DHA supplementation tended to be quantitatively greater in EPC cells but, in particular, the level of EPA was increased in EPC cells to a level over 3-fold greater than in EPC-EFAD cells.

Similar patterns were observed in the fatty acid compositions of polar lipids (Table 4). EPCEFAD cells showed reduced proportions of n- 6 and n-3 PUFA, compensated by increased n-9 PUFA, along with a lower proportion of saturated fatty acids and similar a level of total monounsaturated fatty acids despite EPC-EFAD cells showing a lower proportion of 18:1n-9 compared to EPC cells. As with total lipid, DHA supplementation decreased the proportions of n-9 PUFA and monoenes, particularly 18:1n-9, in polar lipid in both cell lines and increased the proportions of saturated fatty acids, DHA, 22:5n-3, EPA, total n-3PUFA and total PUFA with the percentage of EPA increased in EPC cells to a level over 3-fold greater than in EPC-EFAD cells (Table 4).

The incorporation of $\left[1-{ }^{14} \mathrm{C}\right] 18: 3 \mathrm{n}-3$ was significantly greater in EPC-EFAD cells compared to EPC cells and DHA supplemenation had no significant effect on this (Fig.1). In contrast, the conversion of $\left[1-{ }^{14} \mathrm{C}\right] 18: 3 n-3$ to all desaturation products (sum total of radioactivity recovered as desaturated products including 18:4n-3, 20:4n-3, 22:4n-3, 20:5n-3, 22:5n-3 and 22:6n-3) was not significantly different between EPC and EPC-EFAD cells but DHA supplementation significantly reduced the destauration of $\left[1{ }^{14} \mathrm{C}\right] 18: 3 \mathrm{n}-3$ in both cell lines (Fig.2, top panel). This was mainly a reflection of the effects on the production of tetraene products, which accounted for approximately $45 \%(\mathrm{EPC}+\mathrm{DHA})$ to $64 \%(\mathrm{EPC}-\mathrm{EFAD}+\mathrm{DHA})$ of the total desaturated products 
(Fig.2, middle panel). Pentaenes products accounted for between 33\% (EPC-EFAD + DHA) and $50 \%(\mathrm{EPC}+\mathrm{DHA})$ of the total desturated products and also showed no significant difference between cell line but were significantly reduced in DHA supplemented cells (Fig. 2, bottom panel). However, the reduction in radioactivity recovered in pentaene products was significantly greater in EPC-EFAD cells. Two-way ANOVA confirmed that incorporation of $\left[1-{ }^{14} \mathrm{C}\right] 18: 3 \mathrm{n}-3$ was only affected by cell line and not DHA supplementation, whereas desaturation of [1$\left.{ }^{14} \mathrm{C}\right] 18: 3 \mathrm{n}-3$ to all desaturated products and tetraenes was only significantly affected by DHA supplementation and not by cell line whereas production of pentaene products was also significantly affected by cell line (Table 5). However, the production of DHA from [1$\left.{ }^{14} \mathrm{C}\right] 18: 3 n-3$ was significantly affected by both factors. DHA production from $\left[1-{ }^{14} \mathrm{C}\right] 18: 3 \mathrm{n}-3$ was significantly greater in EPC-EFAD cells compared to EPC cells and DHA supplementation considerably reduced this conversion in EPC-EFAD cells whereas DHA supplementation had little effect on conversion of $\left[1-{ }^{14} \mathrm{C}\right] 18: 3 n-3$ to DHA in EPC cells (Fig. 3). Two-way ANOVA showed the very significant interaction between effects due to cell line and DHA supplementation on DHA production from $\left[1-{ }^{14} \mathrm{C}\right] 18: 3 n-3$, i.e. the effects of DHA supplementation were highly dependent upon cell line and as the difference between EPC and EPC-EFAD cell lines was completely reversed by supplementation with DHA (Table 5). In contrast, the effects due to cell line and DHA supplementation were entirely independent for incorporation and conversion of $\left[1-{ }^{14} \mathrm{C}\right] 18: 3 \mathrm{n}-3$ to other desaturation products (Table 5).

\section{DISCUSSION}

The primary aim of the present study was to determine the effects of DHA, as the end product of the PUFA biosynthetic pathway, on PUFA desaturation/elongation in a cell culture model of EFA deficiency, the EPC-EFAD cell line, in comparison with the non-deficient line, EPC. In 
addition, the study aimed to relate the effects on the PUFA biosynthetic pathway in the cell lines with changes in the fatty acid composition of the cellular lipids. The results of the study have shown that, while the effects of DHA supplementation were similar in both cell lines in some instances, DHA supplementation could have differential effects depending upon the EFA status of the cells. Thus, incorporation of $\left[1-{ }^{14} \mathrm{C}\right] 18: 3 \mathrm{n}-3$ was increased by EFA deficiency but DHA supplementation did not affect these processes. Conversely, the capacity to desaturate [1$\left.{ }^{14} \mathrm{C}\right] 18: 3 \mathrm{n}-3$ to tetraene and pentaene products was not affected by EFA deficiency but was suppressed by DHA supplementation in both cell lines. Significant effects of EFA deficiency on PUFA desaturation were observed mainly on DHA production, with this being increased by EFA deficiency. However, DHA supplementation only significantly inhibited DHA production in EPC-EFAD cells and similarly, the suppression of pentaene production by DHA supplementation was greater in EPC-EFAD cells compared to EPC cells.

Net "incorporation" is based on the recovery of radioactivity in the cells and will be dependent on the initial uptake of fatty acid less the amount of fatty acid oxidized or lost through other metabolic pathways. We had shown previously that incorporation of PUFA is increased in the cell culture model of EFA deficiency, EPC-EFAD cells, compared to their non-deficient parent cells, EPC. ${ }^{3,6}$ In a recent dietary trial, the incorporation of 18:2n-6 and 18:3n-3 was increased in hepatocytes from Atlantic salmon (Salmo salar) fed an EFA deficient diet compared to one fed an n-3-supplemented diet. ${ }^{22}$ The present study has confirmed this result but also showed that prior supplementation of the cells with DHA did not affect the PUFA uptake and incorporation processes in either cell line. The present study was performed under conditions where neither cell line was metabolically predisposed to storing lipid. ${ }^{23}$ This is perhaps obvious with EPC-EFAD cells, being cultured in delipidated FBS, but even culture in $10 \%$ FBS does not lead to the deposition of lipid in the form of lipid droplets in the EPC cell line and so levels of 
neutral lipid in both cell lines are low. ${ }^{3}$ Similarly, we have shown previously that supplementation with PUFA at $20 \mu \mathrm{M}$ is able to significantly alter fatty acid compositions of phospholipids without significantly increasing neutral lipid in these cells. ${ }^{5}$ Therefore, the DHA supplementation used in the present study was sufficient to dramatically increase DHA levels in polar lipids in both cell lines without inducing any increase in neutral lipid stores. In consequence, the results show that an increase in membrane DHA alone did not affect apparent processes of uptake and incorporation of $\left[1-{ }^{14} \mathrm{C}\right] 18: 3 \mathrm{n}-3$. Previously, we found that competing PUFA, added along with $\left[1-{ }^{14} \mathrm{C}\right] 18: 3 n-3$, inhibited the apparent uptake of $\left[1-{ }^{14} \mathrm{C}\right] 18: 3 n-3$, as would be expected, but interestingly the inhibition was significantly less in EPC-EFAD cells compared to EPC cells. ${ }^{6}$

The EPC-EFAD cells have now been cultured continuously in delipidated FBS for over 5 years and 100 passages. Lipid content per cell is lower in the EPC-EFAD cells compared to EPC cells ${ }^{3}$ but the present study showed that the lipid content relative to cell protein is similar in the two cell lines and EFA deficiency had only relatively minor effects on phospholipid class composition. Therefore, the main effects of EFA deficiency were on fatty acid compositions which were characterised in EPC-EFAD cells by increased n-9PUFA, particularly 20:2n-9 and 20:3n-9, balancing the very reduced levels of n-3 and n-6PUFA. The reduced amount of 18:1n9, possibly related to increased metabolism to n-9PUFA, was compensated by increased levels of the other monoenoic fatty acids. These differences between EPC and EPC-EFAD cells are presumably adaptations to maintain the fluidity of the cellular membranes and, consistent with this, reduced cholesterol in the EPC-EFAD cells, as observed in the present study, has also been a consistent feature of EFA deficiency in this cell culture model. ${ }^{3,4}$ Other studies on mammalian cell culture models of EFA deficiency have reported broadly similar changes in fatty acid composition but have not reported lipid class compositions and so the effects of EFA deficiency 
on cholesterol levels in these cells is not known..$^{8-10,24,25}$

The present study clearly demonstrated that there was no difference between EPC and EPCEFAD cells in the amount of $\left[1-{ }^{14} \mathrm{C}\right] 18: 3 n-3$ desaturated to tetraene and pentaene products, i.e. no overall difference in the apparent activities of $\Delta 6$ and $\Delta 5$ desaturases and $\mathrm{C}_{18-20}$ elongase. This is slightly surprising as mammalian dietary studies have generally suggested that $\Delta 6$ (and perhaps $\Delta 5)$ desaturase activities are upregulated by "EFA deficiency" although the dietary modulation has actually been a fat-free diet rather than a diet specifically and solely devoid of PUFA. ${ }^{26}$ However, endocrine/hormonal factors almost certainly have critical roles in regulating fatty acyl desaturase activities in response to nutritional status and so it is probably not appropriate to directly compare cell culture studies with whole animal nutritional trials. ${ }^{27,28}$ Few data are available on fatty acyl desaturase activities in cell culture models of EFA deficiency but it has been reported that both $\Delta 6$ and $\Delta 5$ desaturase activities were upregulated in human HepG 2 cells in EFA deficient conditions although this was a short term, acute deficiency ( 2 weeks) compared to the long-term adapted EPC-EFAD line. ${ }^{29}$ In an earlier study with EPC-EFAD cells, expressing the results as percentage of substrate desaturated rather than the absolute terms used in the present study, we noted that there was increased desaturation of both $\left[1-{ }^{14} \mathrm{C}\right] 18: 3 n-3$ and $\left[1-{ }^{14} \mathrm{C}\right] 18: 2 \mathrm{n}-6$ in EPC-EFAD cells compared to EPC cells. ${ }^{3}$ In that study however, the greatest increase in $\left[1-{ }^{14} \mathrm{C}\right] 18: 3 \mathrm{n}-3$ desaturation in EPC-EFAD cells was in DHA production, which was increased 4.4-fold, with pentenes increased only 1.5-fold and tetraene production actually being 1.4-fold lower in EPC-EFAD cells than in EPC cells. ${ }^{3}$ This is similar to the results in the present study where only DHA production was greater (by 2-fold) in EPC-EFAD cells compared to EPC cells.

DHA supplementation increased the level of DHA and total n-3PUFA, of course, and also decreased n-9PUFA as expected, in both cell lines. The absolute amount of PUFA and their 
relative proportion in total fatty acids was also increased in both cells lines in respose to DHA supplementation, with general membrane fluidity requirements being compensating by increased saturated fatty acids and decreased monoenes, particularly 18:1n-9 which was reduced to similar levels in EPC and EPC-EFAD cells. The effects of DHA supplementation on fatty acid compositions in EPC-EFAD cells were similar to those observed in a previous study which had shown that, like the present study, supplemental DHA was, in part, retroconverted to EPA in EPC-EFAD cells. ${ }^{5}$ However, EPC cells were not investigated in the previous study. The present study has shown that the process of retroconversion was considerably greater in EPC cells such that EPA levels were some 3-fold higher in DHA-supplemented EPC cells than in DHAsupplemented EPC-EFAD cells. DHA levels before DHA supplementation are almost 10-fold higher in EPC cells compared to EPC-EFAD cells and so it appears that this level of DHA, although not high in absolute terms, may result in more of the supplemental DHA being retroconverted. In effect, retroconversion of DHA, which requires saturation of the $\Delta^{4}$ double bond by 2,4-enoyl-CoA reductase and peroxisomal chain shortening via limited $\beta$-oxidation, appears to be inhibited by EFA deficiency. Retroconversion of DHA to 22:5n-3 and EPA has been observed previously in various animal tissues ${ }^{30-32}$ and retroconversion of DHA to 22:5n-3 and EPA, and 22:5n-3 to EPA has been reported in various cells in culture..$^{22,33-35}$ In contrast, in rat $\mathrm{U}_{\mathrm{III}}$ (uterine stromal) cells, which show higher levels of DHA production from 18:3n-3 than most other cell lines, there was no significant retroconversion of DHA, added at $5 \mu \mathrm{M} \cdot{ }^{36}$ To our knowledge the effects of EFA deficiency on retroconversion processes in cell cultures has not been reported previously, but retroconversion of DHA to EPA and 22:5n-3 was reported to be increased in hepatocytes prepared from salmon fed an EFA deficient diet in comparison with hepatocytes from salmon fed an n-3PUFA supplemented diet. ${ }^{22}$

Prior supplementation with DHA also very significantly reduced the 
desaturation/elongation of $\left[1-{ }^{14} \mathrm{C}\right] 18: 3 n-3$ to tetraene and pentaene products in both cell lines. This could be interpreted as being consistent with end-product inhibition as a result of greatly increased membrane DHA levels. Certainly, inhibition or repression of $\Delta 6$ and $\Delta 5$ desaturase activities in response to feeding fish oils, rich in DHA (and EPA) is a consistent observation of dietary trials in mammals. ${ }^{26,37}$ An unexpected result in the present study was the greater effect of DHA in inhibiting DHA and, to a lesser extent, pentaene production in EPC-EFAD cells compared to EPC cells. A possible explanation could be that the level of DHA in EPC cell polar lipids is sufficient to exert a suppressive effect on DHA synthesis that is not increased by a further increase in DHA level but which is reduced by EFA deficiency. This would imply that the presence or absence of end product DHA can only affect DHA production in these cells by an order of 2-fold. An alternative explanation could be that the apparent inability of DHA to inhibit DHA production in EPC cells was related to the level of EPA, produced through retroconversion of the added DHA. Increased EPA may stimulate the conversion of EPA to DHA and thus counteract the suppressive effect of DHA.

In conclusion, the present study determined the effects of DHA, as the end product of the PUFA biosynthetic pathway, on PUFA desaturation/elongation in a cell culture model of EFA deficiency, and attempted to relate the effects on the PUFA biosynthetic pathway with changes in the fatty acid composition of the cellular lipids. The results showed that the effects of DHA supplementation were generally similar in both EPC and EPC-EFAD cells. However, whereas DHA supplementation inhibited biosynthesis of DHA from $\left[1-{ }^{14} \mathrm{C}\right] 18: 3 \mathrm{n}-3$ in EPC-EFAD cells, it had no effect on DHA synthesis in EPC cells. This may be related to the differing levels of DHA and/or EPA between EPC and EPC-EFAD cells both prior and subsequent to DHA supplementation. 


\section{REFERENCES}

1. Takeuchi T., Watanabe T. Requirement of carp for essential fatty acids. Bull Jap Soc Sci Fish 1977; 43: 541-551.

2. Fijan N., Sulimanovic D., Bearzotti M., Muzinic D., Zwillenberg L.O., Chilmonczyk S., Vautherot J. F., de Kinkelin, P. Some properties of the Epithelioma Papulosum Cyprini (EPC) cell line from carp Cyprinus carpio. A Virol (Inst Pasteur) 1983; 134E: 207-220.

3. Tocher D.R., Dick J.R. Polyunsaturated fatty acid metabolism in a cell culture model of essential fatty acid deficiency in a freshwater fish, carp (Cyprinus carpio). Fish Physiol Biochem 1999; 21: 257-267.

4. Tocher D.R. Dick J.R., Sargent J.R. Development of an in vitro model of essential fatty acid deficiency in fish cells. Prostaglandins Leukotrienes Essent Fatty Acids 1995; 53: 365-375.

5. Tocher D.R., Dick J.R., Sargent J.R. Stimulation of proliferation of an essential fatty acid deficienct fish cell line by $\mathrm{C}_{20}$ and $\mathrm{C}_{22}$ polyunsaturated fatty acids and effects on fatty acid composition. Prostaglandins Leukotrienes Essent Fatty Acids 1996; 55: 345-356.

6. Tocher D.R., Dick J.R. Essential fatty acid deficiency in freshwater fish: the effects of linoleic, $\alpha$-linolenic, $\gamma$-linolenic and stearidonic acids on the metabolism of $\left[1-{ }^{14} \mathrm{C}\right] 18: 3 \mathrm{n}-3$ in a carp cell culture model. Fish Physiol Biochem 2000; 22: 67-75.

7. Capriotti A.M., Laposta, M. Identification of variables critical to reproducible delipidation of serum. J Tissue Culture Methods 1986; 10: 219-221.

8. Laposata M., Prescott S.M., Bross T.E., Majerus P.W. Development and characterization of a tissue culture cell line with essential fatty acid deficiency. Proc Natl Acad Sci USA 1982; 79: 7654-7658. 
9. Furth E.E., Sprecher H., Fisher E.A., Fleishman H.D., Laposata M. An in vitro model for essential fatty acid deficiency: Hep G2 cells permanently maintained in lipid free medium. $J$ Lipid Res 1992; 33: 1719-1726.

10. Lerner R., Lindstrom P., Berg A., Johansson E., Rosendahl K., Palmblad J. Development and characterization of essential fatty acid deficiency in human endothelial cells in culture. Proc Natl Acad Sci USA 1995; 92: 1147-1151.

11. Spector A.A., Hoak J.C. An improved method for the addition of long-chain free fatty acids to protein solutions. Anal Biochem 1969; 32: 297-302.

12. Ghioni C., Tocher D.R., Sargent J.R. The effect of culture on morphology, lipid and fatty acid composition, and polyunsaturated fatty acid metabolism of rainbow trout (Oncorhynchus mykiss) skin cells. Fish Physiol Biochem 1997; 16: 499-513.

13. Lowry O.H., Rosebrough N.J., Farr A.L., Randall R.J. Protein measurement with the folin phenol reagent. J Biol Chem 1951; 193: 265-275.

14. Folch J., Lees M., Sloane Stanley G.H. A simple method for the isolation and purification of total lipids from animal tissues. J Biol Chem 1957; 226: 497-509.

15. Tocher D.R., Sargent J.R., Frerichs G.N. The fatty acid compositions of established fish cell lines after long-term culture in mammalian sera. Fish Physiol Biochem 1988; 5: 219-227.

16. Christie W.W. Lipid Analysis, 2nd Edn. Oxford; Pergamon Press, 1982.

17. Tocher D.R., Harvie D.G. Fatty acid compositions of the major phosphoglycerides from fish neural tissues; (n-3) and (n-6) polyunsaturated fatty acids in rainbow trout (Salmo gairdneri) and cod (Gadus morhua) brains and retinas. Fish Physiol Biochem 1988; 5: 229-239.

18. Ackman R.G. Fish lipids part 1. In: Connell J.J., ed. Advances in Fish Science and Technology. Farnham, Surrey: Fishing New Books Ltd, 1980: 86-103. 
19. Bell M. V., Simpson C.M.F., Sargent J.R. (n-3) and (n-6) polyunsaturated fatty acids in the phosphoglycerides of salt-secreting epithelia from two marine fish species. Lipids 1983; 18: 720-726.

20. Wilson R., Sargent J.R. High resolution separation of polyunsaturated fatty acids by argentation thin-layer chromatography. J Chromatogr 1992; 623: 403-407.

21. Zar J.H. Biostatistical Analysis, 2nd Edition. Englewood Cliffs: Prentice-Hall, 1984.

22. Ruyter B., Thomassen M.S. Metabolism of n-3 and n-6 fatty acids in Atlantic salmon liver: Stimulation by essential fatty acid deficiency. Lipids 1999; 34: 1167-1176.

23. Rosenthal M.D. Fatty acid metabolism in cultured mammalian cells. Prog Lipid Res 1987; 26: $87-124$.

24. Marcelo C.L., Duell E.A., Rhodes L.M., Dunham W.R. In vitro model of essential fatty acid deficiency. J Invest Dermatol 1992; 99: 703-708.

25. Marcelo C.L., Dunham W.R. Fatty acid metabolism studies of human epidermal cell cultures. J Lipid Res 1993; 34: 2077-2090.

26. Bezard J., Blond J.P., Bernard A., Clouet P. The metabolism and availability of essential fatty acids in animal and human tissues. Reprod Nutr Dev 1994; 34: 539-568.

27. Brenner R.R. Nutritional and hormonal factors influencing desaturation of essential fatty acids.Prog Lipid Res 1981; 20: 41-47.

28. Brenner R.R. Endocrine control of fatty acid desaturation.Biochem Soc Trans 1990; 18: 773775 .

29. Melin T., Nilsson A. $\Delta 6$ desaturase and $\Delta 5$ desaturase in human Hep G2 cells are both fatty acid interconversion rate limiting and are upregulated under essential fatty acid deficient conditions. Prostaglandins Leukotrienes Essent Fatty Acids 1997; 56: 437-442. 
30. Schlenk H., Sand D.M., Gellerman J.L. Retroconversion of docosahexaenoic acid in the rat. Biochim Biophys Acta 1969; 187: 201-207.

31. Von Schacky C., Weber P.C. Metabolism and effects on platelet function of the purified eicosapentaenoic acids in humans. J Clin Invest 1985; 76: 2446-2450.

32. Brossard N., Croset M., Pachiaudi C., Riou J.P., Tayot J.L., Lagarde M. Retroconversion and metabolism of $\left[{ }^{13} \mathrm{C}\right] 22: 6 n-3$ in humans and rats after intake of a single dose of $\left[{ }^{13} \mathrm{C}\right] 22: 6 n-3$ triacylglycerols. Am J Clin Nutr 1996; 64: 577-586.

33. Rosenthal M.D., Garcia M.C., Jones M.R., Sprecher H. Retroconversion and $\Delta^{4}$ desaturation of docosatetraenoate $(22: 4(n-6))$ and docosapentaenoate $(22: 5(n-3))$ by human cells in culture. Biochim Biophys Acta 1991; 1083: 29-36.

34. Fujiyama-Fujiwara Y., Umeda R., Igarashi O. Metabolism of arachidonic, eicosapentaenoic, and docosahexaenoic acids in HepG2 cells and rat hepatocytes. J Nutr Sci Vitaminol 1992; 38: $329-334$.

35. Brown E.R., Subbaiah P.V. Differential effects of eicosapentaenoic acid and docosahexaenoic acid on human skin fibroblasts. Lipids 1994; 29: 825-829.

36. Pageaux J.-F., Bechoua S., Bonnot G., Fayard J.-M., Cohen H., Lagarde M., Laugier C. Biogenesis and metabolic fate of docosahexaenoic and arachidonic acids in rat uterine stromal cells in culture. Arch Biochem Biophys 1996; 327: 142-150.

37. Cook H.W. Fatty acid desaturation and chain elongation in eukaryotes. In: Vance D.E., Vance J.E., eds. Biochemistry of Lipids, Lipoproteins and Membranes. Amsterdam: Elsevier Press, 1996: 129-152 
page 22 
Legends to Figures

Fig.1. Effects of supplementation with $22: 6 n-3$ on the incorporation of $\left[1-{ }^{14} \mathrm{C}\right] 18: 3 n-3$ into EPC and EPC-EFAD cells. Results are presented as means \pm S.D. of triplicate experiments. Mean values with different letters are significantly different $(\mathrm{P}<0.05)$ as determined by one-way analysis of variation (ANOVA) followed by Tukey's post-test. $\square$, unsupplemented and $\square$, supplemented with $20 \mu \mathrm{M}$ 22:6n-3 as described in the Materials and Methods section.

Fig.2. Effects of supplementation with $22: 6 n-3$ on the desaturation of $\left[1-{ }^{14} \mathrm{C}\right] 18: 3 n-3$ in EPC and EPC-EFAD cells. Panels represent the amount of $\left[1-{ }^{14} \mathrm{C}\right] 18: 3 n-3$ converted to all desaturated products (sum total of radioactivity recovered as 18:4n-3, 20:4n-3, 22:4n-3, 20:5n-3, 22:5n-3 and 22:6n-3) (top panel), tetraene products (total radioactivity recovered as 18:4n-3, 20:4n-3 and 22:4n-3) (middle panel) and pentaene products (total radioactivity recovered as 20:5n-3 and 22:5n-3) (bottom panel). Results are presented as means \pm S.D. of triplicate experiments. Mean values with different letters are significantly different $(\mathrm{P}<0.05)$ as determined by one-way analysis of variation (ANOVA) followed by Tukey's post-test. $\square$, unsupplemented and $\square$, supplemented with $20 \mu \mathrm{M}$ 22:6n-3 as described in the Materials and Methods section.

Fig.3. Effects of supplementation with $22: 6 n-3$ on the production of $22: 6 n-3$ from $\left[1-{ }^{14} \mathrm{C}\right] 18: 3 n-3$ in EPC and EPC-EFAD cells. Results represent the amount of $\left[1-{ }^{14} \mathrm{C}\right] 18: 3 n-3$ converted to 22:6n-3 and are presented as means \pm S.D. of triplicate experiments. Mean values with different letters are significantly different $(\mathrm{P}<0.05)$ as determined by one-way analysis of variation 
(ANOVA) followed by Tukey's post-test. $\square$, unsupplemented and $\square$, supplemented with 20 $\mu \mathrm{M}$ 22:6n-3 as described in the Materials and Methods section. 
Fig.1.

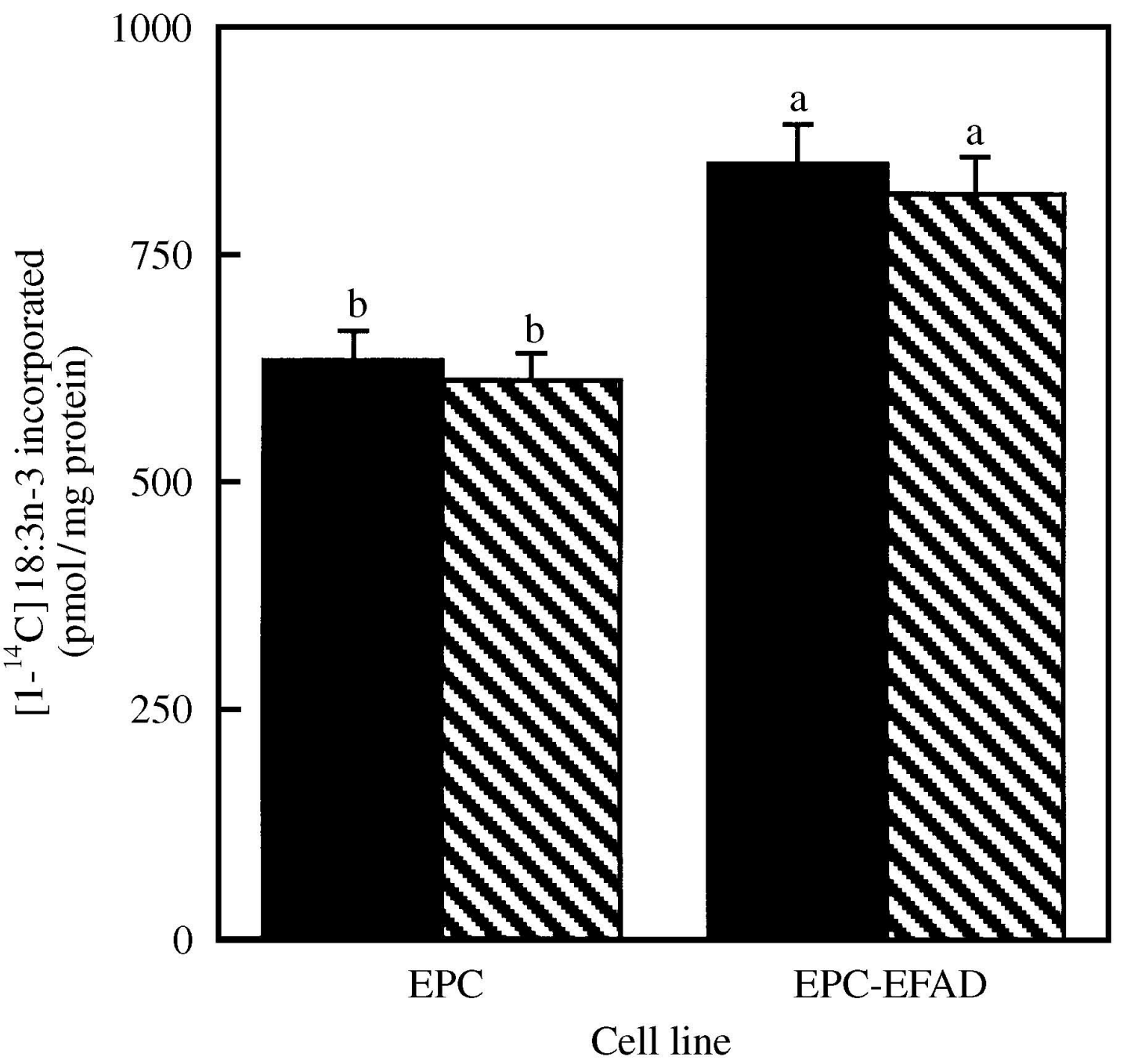

page 25 
Fig.2.

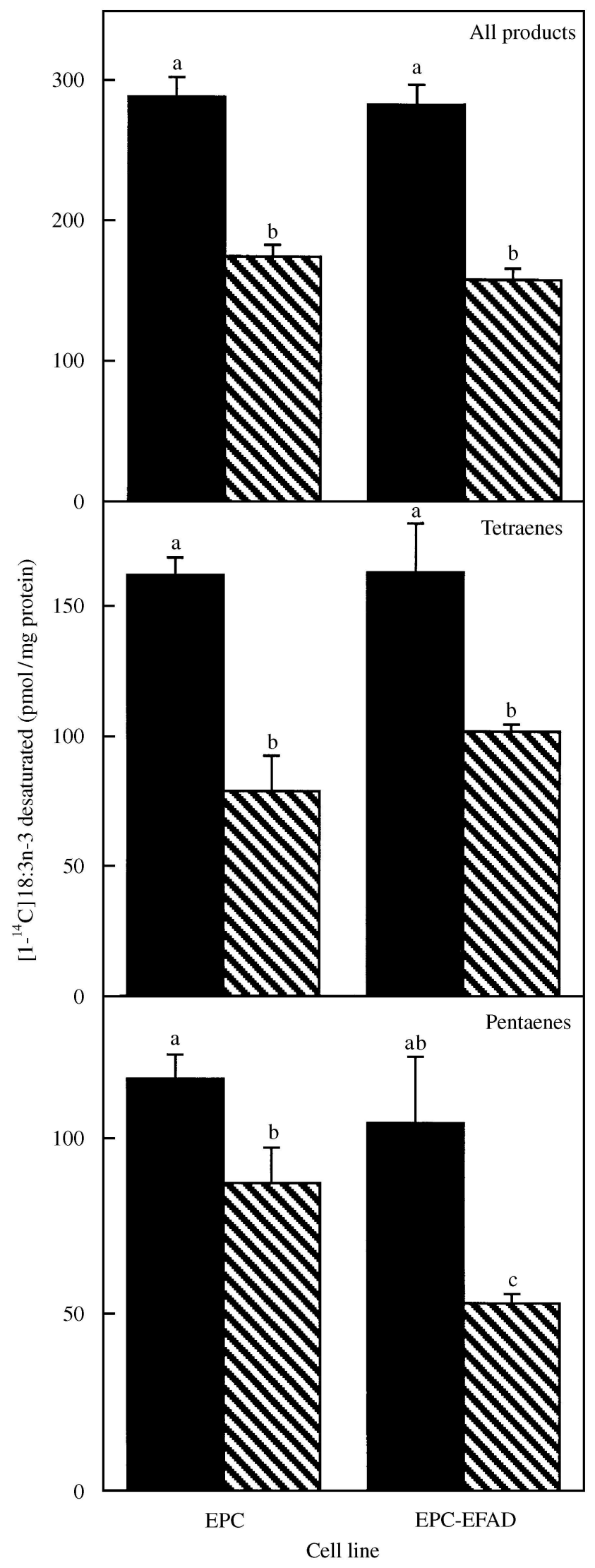

page 26 
Fig.3.

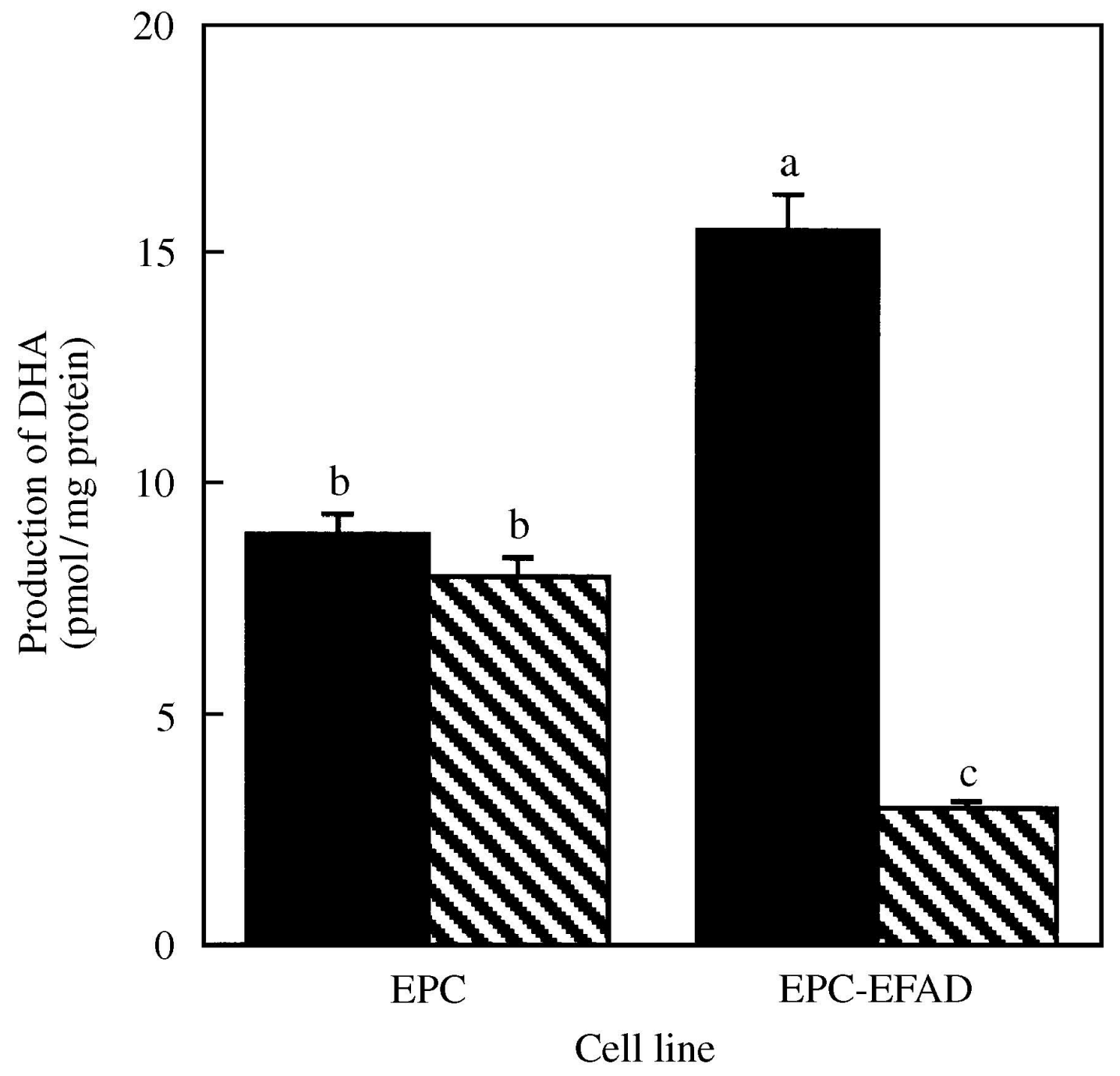

page 27 
Table 1. Effect of supplementation with 22:6n-3 (DHA) on lipid content and lipid class composition (percentage of total lipid) of total lipid from EPC and EPC-EFAD cells.

\begin{tabular}{|c|c|c|c|c|c|c|c|c|c|c|c|c|}
\hline \multirow{2}{*}{$\begin{array}{l}\text { Cell line } \\
\text { Supplement }\end{array}$} & \multicolumn{6}{|c|}{$\mathrm{EPC}$} & \multicolumn{6}{|c|}{ EPC-EFAD } \\
\hline & \multicolumn{3}{|c|}{ None } & \multicolumn{3}{|c|}{ DIIA } & \multicolumn{3}{|c|}{ None } & \multicolumn{3}{|c|}{ DIIA } \\
\hline Lipid content & 221 & \pm & 15 & 243 & \pm & 10 & 234 & \pm & 1 & 208 & \pm & 11 \\
\hline \multicolumn{13}{|c|}{$\left(\mu \mathrm{g} . \mathrm{mg}\right.$ protein $\left.{ }^{-1}\right)$} \\
\hline & & & & & & & & & & & & \\
\hline \multicolumn{13}{|c|}{ Class composition } \\
\hline $\mathrm{PC}$ & 21.8 & \pm & 0.8 & 23.7 & \pm & 0.1 & 19.7 & \pm & (). 2 & 18.8 & \pm & 0.6 \\
\hline $\mathrm{PE}$ & 22.0 & \pm & 0.7 & 20.9 & \pm & 0.1 & 24.1 & \pm & 0.1 & 24.6 & \pm & 0.3 \\
\hline PS & 7.1 & \pm & 0.1 & 7.7 & \pm & 0.2 & 6.2 & \pm & 0.1 & 7.3 & \pm & 0.4 \\
\hline PI & 6.4 & \pm & 0.1 & 6.0 & \pm & 0.1 & 8.3 & \pm & 0.2 & 8.4 & \pm & 0.3 \\
\hline $\mathrm{PA} / \mathrm{CL}$ & 3.9 & \pm & 0.1 & 4.7 & \pm & 0.2 & 4.6 & \pm & 0.1 & 5.9 & \pm & 0.0 \\
\hline Sphingomyelin & 8.5 & \pm & 0.3 & 8.7 & \pm & 0.3 & 7.8 & \pm & 0.3 & 8.4 & \pm & 0.1 \\
\hline Cer/Sulf & 0.4 & \pm & 0.4 & 0.3 & \pm & 0.0 & 3.8 & \pm & 0.2 & 2.1 & \pm & 0.1 \\
\hline Tot. polars & 70.1 & \pm & 0.3 & 72.0 & \pm & 0.7 & 74.5 & \pm & 0.2 & 75.5 & \pm & 0.5 \\
\hline Tot. neutrals & 29.9 & \pm & 0.3 & 28.0 & \pm & 0.7 & 25.5 & \pm & 0.2 & 24.5 & \pm & 0.5 \\
\hline Cholesterol & 27.5 & \pm & 0.7 & 24.8 & \pm & 0.6 & 23.3 & \pm & 0.1 & 23.4 & \pm & 0.7 \\
\hline Triacylglycerol & 1.4 & \pm & 0.2 & 0.8 & \pm & 0.1 & 2.2 & \pm & 0.1 & 1.1 & \pm & 0.2 \\
\hline Free fatty acid & \multicolumn{3}{|c|}{ n.d. } & \multicolumn{3}{|c|}{ n.d. } & \multicolumn{3}{|c|}{ n.d. } & \multicolumn{3}{|c|}{ n.d. } \\
\hline Steryl ester & 1.0 & \pm & 0.4 & 2.4 & \pm & 0.8 & & $\operatorname{tr}$ & & & $\operatorname{tr}$ & \\
\hline
\end{tabular}

Results are means $\pm \mathrm{SD}(\mathrm{n}=3)$. Cer/Sulf, cerebrosides and sulfatides;

CL, cardiolipin; n.d., not detected; PA, phosphatidic acid; PC, phosphatidylcholine;

PE, phosphatidylethanolamine; PI, phosphatidylinositol; PS, phosphatidylserine; n.d., not detected; tr, trace $(<0.1 \%)$. 
Table 2. Results of two-way analysis of variance (ANOVA) for the significance of differences due to cell line and DHA supplement on the lipid content and lipid class composition of EPC and EPC-EFAD cells.

\begin{tabular}{|c|c|c|c|c|c|}
\hline Parameter & Treatment & $\mathrm{P}$ & F value & significance & rank order \\
\hline \multirow{3}{*}{ Lipid content } & cell line & 0.1092 & 3.25 & ns & \\
\hline & DHA supplement & 0.7516 & 0.11 & ns & \\
\hline & interaction & 0.0043 & 15.46 & $*$ & \\
\hline \multirow[t]{3}{*}{ Total polar lipid } & cell line & $<0.0001$ & 215.21 & * & EFAD $>$ EPC \\
\hline & DHA supplement & 0.0007 & 29.00 & $*$ & DHA $>$ none \\
\hline & interaction & 0.1332 & 2.79 & ns & \\
\hline \multirow{3}{*}{ Total neutral lipid } & cell line & $<0.0001$ & 215.21 & $*$ & $\mathrm{EPC}>\mathrm{EFAD}$ \\
\hline & DHA supplement & 0.0007 & 29.00 & $*$ & none $>$ DHA \\
\hline & interaction & 0.1332 & 2.79 & ns & \\
\hline \multirow[t]{3}{*}{$\mathrm{PC}$} & cell line & $<0.0001$ & 140.00 & * & $\mathrm{EPC}>\mathrm{EFAD}$ \\
\hline & DIIA supplement & 0.1294 & 2.86 & ns & \\
\hline & interaction & 0.0015 & 22.40 & * & \\
\hline \multirow[t]{3}{*}{$\mathrm{PE}$} & cell line & $<0.0001$ & 168.20 & * & EFAD $>$ EPC \\
\hline & DHA supplement & 0.2165 & 1.80 & ns & \\
\hline & interaction & 0.0072 & 12.80 & * & \\
\hline \multirow[t]{3}{*}{ PS } & cell line & 0.0014 & 23.05 & * & $\mathrm{EPC}>\mathrm{EFAD}$ \\
\hline & DHA supplement & 0.0002 & 39.41 & * & DHA > none \\
\hline & interaction & 0.1020 & 3.41 & ns & \\
\hline \multirow[t]{3}{*}{ PI } & cell line & $<0.0001$ & 369.80 & $*$ & EFAD > EPC \\
\hline & DHA supplement & 0.2165 & 1.80 & ns & \\
\hline & interaction & 0.0558 & 5.00 & ns & \\
\hline \multirow[t]{3}{*}{$\mathrm{PA} / \mathrm{CL}$} & cell line & $<0.0001$ & 180.50 & $*$ & $\mathrm{EFAD}>\mathrm{EPC}$ \\
\hline & DHA supplement & $<0.0001$ & 220.50 & $*$ & DHA $>$ none \\
\hline & interaction & 0.0077 & 12.50 & $*$ & \\
\hline \multirow[t]{3}{*}{ SM } & cell line & 0.0113 & 10.71 & $*$ & $\mathrm{EPC}>\mathrm{EFAD}$ \\
\hline & DHA supplement & 0.0307 & 6.86 & $*$ & DHA > none \\
\hline & interaction & 0.2268 & 1.71 & ns & \\
\hline \multirow[t]{3}{*}{ Cer/Sulf } & cell line & $<0.0001$ & 386.29 & $*$ & EFAD $>$ EPC \\
\hline & DHA supplement & 0.0001 & 46.29 & * & none $>$ DHA \\
\hline & interaction & 0.0003 & 36.57 & * & \\
\hline \multirow[t]{3}{*}{ Cholesterol } & cell line & $<0.0001$ & 69.69 & * & EPC $>$ EFAD \\
\hline & DHA supplement & 0.0047 & 15.02 & * & none $>$ DHA \\
\hline & interaction & 0.0031 & 17.42 & $*$ & \\
\hline \multirow[t]{3}{*}{ Triacylglycerol } & cell line & 0.0003 & 36.3 & * & EFAD $>$ EPC \\
\hline & DHA supplement & $<0.0001$ & 86.70 & * & none $>$ DHA \\
\hline & interaction & 0.0255 & 7.50 & * & \\
\hline \multirow[t]{3}{*}{ Steryl ester } & cell line & 0.0002 & 43.35 & * & EPC $>$ EFAD \\
\hline & DHA supplement & 0.0266 & 7.35 & * & DHA > none \\
\hline & interaction & 0.0266 & 7.35 & * & \\
\hline \multicolumn{3}{|c|}{ *, effect is significant; ns, not significant. } & & & \\
\hline & & & & & \\
\hline
\end{tabular}


Table 3. Effect of supplementation with 22:6n-3 (DHA) on fatty acid composition ( $\mu$ g.mg protein ${ }^{-1}$ ) of total lipid from EPC and EPC-EFAD cells.

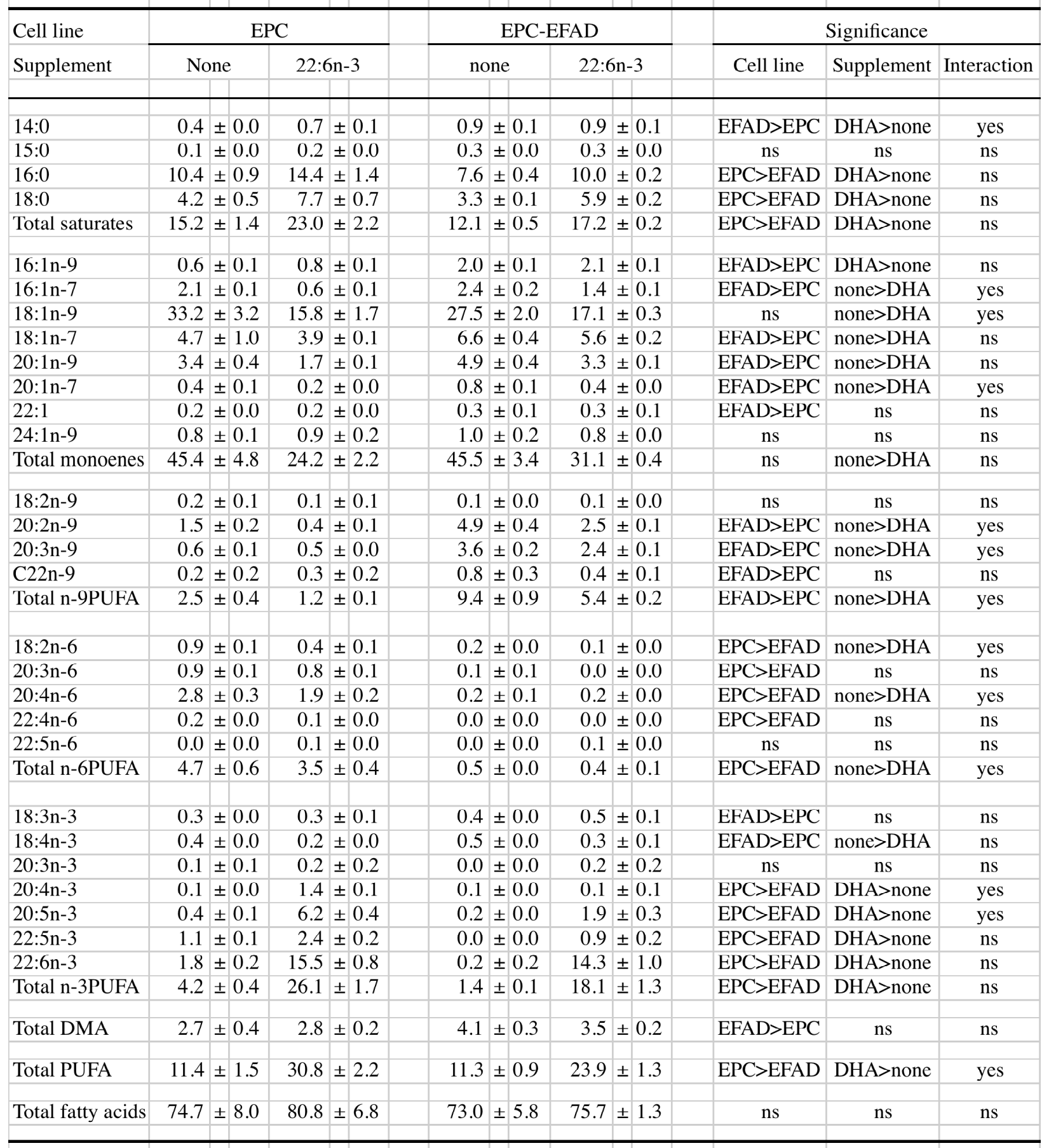

Results are presented as means \pm S.D. $(n=3)$. DMA, dimethylacetals; PUFA, polyunsaturated fatty acids.

Data within a row were subjected to two-way analysis of variance (ANOVA) for significance of effects due to cell line and DHA supplement. Significant differences are indicated in the Table by denoting the rank order. ns, not significant. 
Table 4. Effect of supplementation with 22:6n-3 (DHA) on fatty acid composition (percentage of total fatty acids) of total polar lipid from EPC and EPC-EFAD cells.

\begin{tabular}{|c|c|c|c|c|c|c|c|c|c|c|c|c|c|c|}
\hline \multirow{2}{*}{$\begin{array}{l}\text { Cell line } \\
\text { Supplement }\end{array}$} & \multicolumn{6}{|c|}{ EPC } & \multicolumn{5}{|c|}{ EPC-EFAD } & \multicolumn{3}{|c|}{ Significance } \\
\hline & \multicolumn{3}{|c|}{ None } & \multicolumn{3}{|c|}{$22: 6 n-3$} & \multicolumn{2}{|c|}{ None } & \multicolumn{3}{|c|}{$22: 6 n-3$} & Cell line & Supplement & Interaction \\
\hline & & & & & & & & & & & & & & \\
\hline $14: 0$ & 0.5 & \pm & $=0.0$ & 0.9 & \pm & 0.1 & 1.2 & \pm 0 . & 1.6 & & 0.1 & EFAD $>E P C$ & DHA>none & ns \\
\hline $15: 0$ & 0.1 & \pm & $=0.0$ & 0.3 & \pm & 0.0 & 0.5 & \pm 0 & 0.5 & \pm( & 0.0 & EFAD $>E P C$ & ns & ns \\
\hline $16: 0$ & 13.7 & \pm & $=0.1$ & 18.4 & \pm & 0.1 & 10.0 & \pm 0. & 13.5 & \pm & 0.2 & $\mathrm{EPC}>\mathrm{EFAD}$ & DIIA $>$ none & yes \\
\hline $18: 0$ & 5.6 & \pm & $=0.1$ & 9.5 & \pm & 0.1 & 4.2 & \pm 0 & 7.4 & \pm & 0.1 & EPC $>$ EFAD & DHA $>$ none & yes \\
\hline Total saturates & 20.0 & \pm & $=0.2$ & 29.0 & \pm & 0.2 & 15.9 & \pm 0. & 23.0 & \pm & 0.4 & $\mathrm{EPC}>\mathrm{EFAD}$ & DHA $>$ none & yes \\
\hline $16: 1 n-9$ & 0.8 & \pm & $=0.0$ & 1.0 & \pm & 0.0 & 2.8 & \pm 0 . & 3.0 & \pm & 0.0 & EFAD $>$ EPC & DHA>none & ns \\
\hline $16: 1 n-7$ & 3.0 & \pm & $=0.0$ & 0.7 & \pm & 0.0 & 3.5 & \pm 0 . & 2.1 & \pm & 0.0 & EFAD $>$ EPC & DHA $>$ none & yes \\
\hline $18: 1 n-9$ & 44.8 & \pm & $=0.5$ & 19.8 & \pm & 0.5 & 38.6 & \pm 0 . & 22.4 & \pm & 0.7 & $\mathrm{EPC}>\mathrm{EFAD}$ & nonc $>$ DHA & yes \\
\hline $18: 1 n-7$ & 7.0 & \pm & $=0.1$ & 4.8 & \pm & 0.5 & 9.1 & \pm 0 . & 7.3 & \pm 1 & 0.3 & EFAD $>$ EPC & none $>$ DHA & $\mathrm{ns}$ \\
\hline $20: 1 n-9$ & 4.5 & \pm & $=0.0$ & 2.1 & \pm & 0.0 & 6.6 & \pm 0 & 4.2 & \pm( & 0.1 & EFAD $>$ EPC & none $>$ DHA & $\mathrm{ns}$ \\
\hline $20: 1 n-7$ & 0.6 & \pm & $=0.0$ & 0.3 & \pm & 0.0 & 1.3 & \pm 0 . & 0.6 & \pm & 0.0 & EFAD $>$ EPC & none $>$ DHA & yes \\
\hline $22: 1$ & 0.3 & \pm & $=0.1$ & 0.2 & \pm & 0.0 & 0.4 & \pm 0 . & 0.5 & \pm( & 0.1 & EFAD $>E P C$ & ns & $\mathrm{ns}$ \\
\hline $24: 1 n-9$ & 0.8 & \pm & $=0.4$ & 0.7 & \pm & 0.3 & 1.5 & \pm 0 & 1.5 & \pm & 0.0 & EFAD $>$ EPC & ns & ns \\
\hline Total monoenes & 61.7 & \pm & $=0.4$ & 29.6 & \pm & 0.3 & 63.6 & \pm 0 . & 41.4 & \pm & 0.8 & EFAD $>E P C$ & none $>$ DHA & yes \\
\hline $18: 2 n-9$ & 0.2 & \pm & $=0.0$ & 0.1 & \pm & 0.0 & 0.2 & \pm 0 . & 0.1 & \pm( & 0.1 & $\mathrm{~ns}$ & none $>$ DHA & ns \\
\hline $20: 2 n-9$ & 2.1 & \pm & $=0.1$ & 0.5 & \pm & 0.1 & 6.8 & \pm 0 & 3.3 & \pm & 0.2 & EFAD $>$ EPC & none $>$ DHA & yes \\
\hline $20: 3 n-9$ & 0.8 & \pm & $=0.1$ & 0.6 & \pm & 0.1 & 5.1 & \pm 0 & 3.3 & \pm & 0.3 & EFAD $>E P C$ & none $>$ DHA & yes \\
\hline$C 22 n-9$ & 0.0 & \pm & $=0.1$ & 0.0 & \pm & 0.1 & 0.4 & \pm 0 . & 0.2 & \pm( & 0.0 & EFAD $>$ EPC & none $>$ DIIA & yes \\
\hline Total n-9PUFA & 3.1 & \pm & $=0.3$ & 1.2 & \pm & 0.1 & 12.6 & \pm 0 & 6.8 & \pm & 0.5 & EFAD $>$ EPC & none $>$ DHA & yes \\
\hline $18: 2 n-6$ & 1.1 & \pm & $=0.0$ & 0.5 & \pm & 0.0 & 0.2 & \pm 0 & 0.2 & \pm( & 0.0 & EPC $>$ EFAD & none $>$ DHA & yes \\
\hline $20: 3 n-6$ & 1.2 & \pm & $=0.1$ & 1.0 & \pm & 0.1 & 0.1 & \pm 0 & 0.0 & \pm & 0.0 & $\mathrm{EPC}>\mathrm{EFAD}$ & none $>$ DHA & $\mathrm{ns}$ \\
\hline $20: 4 n-6$ & 3.7 & \pm & $=0.1$ & 2.5 & \pm & 0.1 & 0.1 & \pm 0 . & 0.1 & \pm & 0.0 & EPC $>$ EFAD & none $>$ DHA & yes \\
\hline $22: 4 n-6$ & 0.2 & \pm & $=0.1$ & 0.1 & \pm & 0.1 & 0.0 & \pm 0 & 0.0 & \pm 1 & 0.0 & $\mathrm{EPC}>\mathrm{EFAD}$ & ns & $\mathrm{ns}$ \\
\hline $22: 5 n-6$ & 0.0 & \pm & $=0.0$ & 0.2 & \pm & 0.0 & 0.0 & \pm 0 . & 0.2 & \pm( & 0.0 & ns & DHA>none & ns \\
\hline Total n-6PUFA & 6.2 & \pm & $=0.1$ & 4.2 & \pm & 0.2 & 0.4 & \pm 0 . & 0.5 & \pm & 0.1 & EPC $>$ EFAD & none $>$ DHA & yes \\
\hline $18: 3 n-3$ & 0.4 & \pm & $=0.0$ & 0.4 & \pm & 0.1 & 0.5 & \pm 0 . & 0.7 & \pm 1 & 0.1 & EFAD $>$ EPC & $\mathrm{DHA}>$ none & yes \\
\hline $18: 4 n-3$ & 0.5 & \pm & $=0.1$ & 0.3 & \pm & 0.0 & 0.6 & \pm 0 . & 0.4 & \pm & 0.0 & EFAD $>$ EPC & none $>$ DHA & $\mathrm{ns}$ \\
\hline $20: 3 n-3$ & 0.1 & \pm & 0.1 & 0.2 & \pm & 0.2 & 0.0 & \pm 0 . & 0.2 & \pm & 0.3 & ns & ns & ns \\
\hline $20: 4 n-3$ & 0.0 & \pm & $=0.1$ & 1.7 & \pm & 0.0 & 0.3 & \pm 0 . & 0.1 & \pm( & 0.1 & $\mathrm{EPC}>\mathrm{EFAD}$ & DHA $>$ none & yes \\
\hline $20: 5 n-3$ & 0.4 & \pm & $=0.1$ & 7.9 & \pm & 0.1 & 0.2 & \pm 0 & 2.5 & \pm( & 0.4 & $\mathrm{EPC}>\mathrm{EFAD}$ & DHA>none & yes \\
\hline $22: 5 n-3$ & 1.6 & \pm & $=0.0$ & 3.0 & \pm & 0.0 & 0.0 & \pm 0 & 1.3 & \pm & 0.2 & EPC $>$ EFAD & DHA>none & ns \\
\hline $22: 6 n-3$ & 2.5 & \pm & $=0.0$ & 19.2 & \pm & 0.3 & 0.3 & \pm 0 . & 18.6 & \pm & 0.5 & $\mathrm{EPC}>\mathrm{EFAD}$ & DHA $>$ none & ns \\
\hline Total n-3PUFA & 5.5 & \pm & $=0.0$ & 32.7 & \pm & 0.4 & 1.9 & \pm 0 & 23.8 & \pm & 0.7 & EPC $>$ EFAD & DHA $>$ none & ns \\
\hline Total DMA & 3.5 & \pm & $=0.2$ & 3.3 & \pm & 0.1 & 5.5 & \pm 0 . & 4.4 & \pm & 0.2 & EFAD $>E P C$ & none $>$ DHA & yes \\
\hline Total PUFA & 14.8 & \pm & $=0.2$ & 38.1 & \pm & 0.4 & 14.9 & \pm 0 & 31.1 & \pm & 0.4 & $\mathrm{EPC}>\mathrm{EFAD}$ & $\mathrm{DHA}>$ none & yes \\
\hline
\end{tabular}

Results are presented as means \pm S.D. $(n=3)$. DMA, dimethylacetals; PUFA, polyunsaturated fatty acids.

Data within a row were subjected to two-way analysis of variance (ANOVA) for significance of cffects duc to cell line and DHA supplement. Significant differences are indicated in the Table by denoting the rank order. ns, not significant. 
Table 5. Results of two-way analysis of variance (ANOVA) for the significance of differences due to cell line and DHA supplement on the incorporation of $\left[1-{ }^{14} \mathrm{C}\right] 18: 3 \mathrm{n}-3$ and the amount of $\left[1-{ }^{14} \mathrm{C}\right] 18: 3 n-3$ converted to various desaturation products in EPC and EPC-EFAD cells.

\begin{tabular}{|c|c|c|c|c|c|}
\hline Parameter & Treatment & $\mathrm{P}$ & F value & significance & rank order \\
\hline & & & & & \\
\hline \multirow[t]{3}{*}{ Incorporation } & cell line & $<0.0001$ & 71.52 & $*$ & $\mathrm{EFAD}>\mathrm{EPC}$ \\
\hline & DHA supplement & 0.3014 & 1.22 & $\mathrm{~ns}$ & \\
\hline & interaction & 0.8307 & 0.05 & ns & \\
\hline \multirow[t]{3}{*}{ All desat. prods. } & cell line & 0.5373 & 0.42 & ns & \\
\hline & DHA supplement & $<0.0001$ & 54.78 & $*$ & none $>$ DHA \\
\hline & interaction & 0.7385 & 0.12 & ns & \\
\hline \multirow[t]{3}{*}{ Tetraene products } & cell line & 0.1857 & 2.1 & ns & \\
\hline & DHA supplement & $<0.0001$ & 72.79 & $*$ & none $>$ DHA \\
\hline & interaction & 0.232 & 1.67 & ns & \\
\hline \multirow[t]{3}{*}{ Pentaene products } & cell line & 0.0074 & 12.69 & $*$ & $\mathrm{EPC}>\mathrm{EFAD}$ \\
\hline & DHA supplement & 0.0003 & 38.48 & $*$ & none $>$ DHA \\
\hline & interaction & 0.1358 & 2.75 & ns & \\
\hline \multirow[t]{3}{*}{ DHA production } & cell line & 0.3415 & 1.02 & ns & \\
\hline & DHA supplement & $<0.0001$ & 71.73 & $*$ & none $>$ DHA \\
\hline & interaction & $<0.0001$ & 53.75 & $*$ & \\
\hline \multicolumn{6}{|c|}{ All desat. prods., sum of radioactivity recovered as 18:4, 20:4, 22:4, 20:5, 22:5 and 22:6; } \\
\hline \multicolumn{6}{|c|}{ Tetraene products, sum of radioactivity recovered as 18:4, 20:4 and 22:4; Pentaene products, } \\
\hline
\end{tabular}

